\title{
Anal Canal Large Cell Neuroendocrine Carcinoma
}

National Cancer Institute

\section{Source}

National Cancer Institute. Anal Canal Large Cell Neuroendocrine Carcinoma. NCI

Thesaurus. Code C96550.

An aggressive, high-grade and poorly differentiated carcinoma with neuroendocrine differentiation that arises from the anal canal. It is characterized by the presence of malignant large cells. 